\title{
THE ADVENT OF THE PHANEROZOIC WORLD: VENDIAN STRATIGRAPHY, ENVIRONMENTAL CHANGE, AND EVOLUTION
}

\author{
KNOLL, Andrew H., Botanical Museum, Harvard University, Cambridge MA 02138, U.S.A.
}

The Vendian interval (ca. 610-540 Ma) links Proterozoic and Phanerozoic worlds of sharply contrasting character. Despite decades of study, the nature of this transition remains unclear, in part because of our limited ability to correlate Vendian successions or evaluate shifts in global environments. New data on secular variations in the $\mathrm{C}$ and $\mathrm{Sr}$ isotopic compositions of Vendian carbonates (and organic matter) provide an improved stratigraphic and biogeochemical framework for understanding latest Proterozoic biological and environmental evolution.

Biologically, the Vendian interval is best known for the Ediacaran radiation of macroscopic animals, but this event is set within a broader Neoproterozoic diversification of higher eukaryotes. All three principal groups of multicellular algae radiated well before the beginning of the Vendian, as did a host of unicellular protists. In particular, successions deposited immediately after the Varanger Ice Age (ca. $610-590 \mathrm{Ma}$ ) are characterized by a high diversity of large and morphologically complex acritarchs; most of these forms disappeared after the first appearance of Ediacara-grade metazoans but before the eponymous fauna preserved in South Australia.

Stratigraphic ordering of the earliest faunas is made possible by chemostratigraphy. Contrary to some published expectations, the morphologically complex petalonemids and skeletalized cloudinids of the lower Nama Group, Namibia, appear to predate, perhaps significantly, the classic faunas of South Australia, eastern Siberia, and elsewhere. Zircon ages for tuffs promise an absolute chronology for biological and biogeochemical events. The presence in pre-Cambrian rocks of Cloudina, calcareous algae and (?)siliceous discs comparable to chrysophyte scales demonstrates that eukaryotic calcite, aragonite, and silica biomineralization all predate the beginning of the Cambrian; however, sedimentological and petrographic features of carbonates and cherts suggest that skeletons first emerged as globally significant components of the carbon and silica cycles with the basal Cambrian radiation.

Vendian evolution must also be evaluated within a broader context of environmental change. The $\mathrm{Sr}$ and $\mathrm{C}$ isotopic data that enhance stratigraphic correlation also record patterns of hydrothermal emission and organic carbon burial that must have affected $\mathrm{pO}_{2}$. Independent models by Derry and others and Knoll and Walker suggest that latest Proterozoic reductions in the hydrothermal flux of reduced materials into the oceans coupled with high burial rates of organic carbon resulted in a significant increase in global oxygen levels immediately prior to the great Ediacaran radiation.

Many questions about Vendian evolution remain unresolved. Some will surely require fresh insights into the development and functional morphology of early metazoans, but it is becoming increasingly clear that a satisfactory accounting of Ediacaran animal diversification will not be achieved without a better understanding of the stratigraphic, environmental, and biological context in which it occurred. 